\title{
Documentos de los teólogos asiáticos
}

Segunda Asamblea General de la Asociación Ecuménica de Teólogos del Tercer Mundo, Oaxtepec, México, 7-14 de diciembre de 1986.

\section{Realidades socioeconómicas y políticas}

\section{A. Asia}

1. De todas las regiones del mundo, Asia es quizás la que presenta mayores dificultades cuando se intenta generalizar su realidad.

1.1. En túrminos geográficos, Asia es de vasta extensión y está configurada por palses que abarcan grandes territorios, como los casos de China e India y de muchos que son de tipo insular, desconectados entre sí y del resto de la tierra furme por grandes mares, por ejemplo, Filipinas, Indonesia y Japón.

1.2. Demográficamente, los países más poblados del mundo se encuentran en la región asiática, es decir China y la India el primero con más de mil millones de habitantes y el segundo con más de 700 millones. Si se suma a éstos la población de los demás países, en Asia vive un 58 por ciento de la población mundial. De ahl que Asia posea la mayor fuerza de trabajo y sea potencialmente el mayor mercado para productos manufacturados.

1.3. En términos económicos, la región está configurada por países que han alcanzado muy variados niveles de desarrollo y crecimiento económicos, con algunos paises, como Japón, que han logrado un nivel de progreso económico y tecnológico a la altura del primer mundo, mientras que otros, como Bangladesh, están considerados entre los más pobres del mundo.

1.4. En términos políticos, Asia es también una región que muestra una gran variedad de regimenes políticos. Hay paises en que se gobierna según las formas básicas de las democracias parlamentarias liberales, por ejemplo, Japón; otros en que se gobiema según formas autoritarias en la línea del Estado de Seguridad Nacional; mientras otros estín en el ámbito de reglmenes socialistas, como Birmania, China, Laos, Viet Nam, Kampuchea y Corea del Norte.

1.5. A pecar de esta variedad, que dificulta delinear semejanzas, creemos que nuestra tarea teológica debe dirigirse a y situarse en un contexto de realidades 
socioeconómicas y políticas que puedan ser descritas de acuerdo a ciertas categorías temáticas.

2. Existe, en primer lugar, la realidad duradera de pobreza y miseria, escandalosa y extendida, en la cual viven grandes mayorías en cada país junto al abominable lujo y opulencia que disfruta un grupo relativamente pequeflo. El nivel de pobreza y el grado de disparidad entre los ricos y los pobres varfa de un país a otro.

2.1. Japon ha alcanzado un nivel de crecimiento económico y de productividad al que el porcentaje de población "pobre" es relativamente menor que en la mayoría de los países asiálicos, mientras que los niveles de ingreso y de vida de la población en general es relativamente mayor que en la mayoria de estos paises

2.2. Los llamados milagros económicos que se han dado en Corea del Sur, Hong Kong, Singapur y Taiwan, también han elevado el producto nacional bruto y el ingreso per cápita en esos países.

2.3. Existen paises que han alcanzado un nivel "medio" de desarrollo económico, tales como Indonesia y Malasia, donde la explotación de vastos recursos naturales ha generado un crecimiento significativo y ha reducido los niveles de pobreza en aftos recientes.

2.4. La India, aunque todavia un pais pobre, es actualmente la décima potencia industrial del mundo.

2.5. Existen países cuyo crecimiento económico ha sido bastante lento y cuya población sufre la pobreza en alta proporción. Por ejemplo, tanto en Filipinas como en Bangladesh se estima que el 80 por ciento de la población vive en condiciones de pobreza extrema.

2.6. China se encuentra en una situación distinta. Si bien es cierto que su ingreso per cápita permanece bajo, ha logrado, no osbtante, una nivelación muy alta del nivel de vida entre su enorme población y ha tenido éxilo en la satisfacción de las necesidades básicas y los servicios esenciales que demanda la sociedad, evilando a la vez una inflación en gran escala.

3. Cuando se rellexiona sobre estos datos con mayor detenimiento, sin embargo, se constata que, de promedio, solamente un 10-15 por ciento de la población total de Asia vive en relativo confort, mientras que el resto sobrevive todavía en condiciones de escandalosa pobreza. Esta pobreza que abate a grandes masas de la población, a pesar de los pronunciamientos que alardean de milagros y progresos económicos, da testimonio de una realidad socioeconómica fundamental: la enorme diferencia y la evidente distribución desigual de la riqueza y et poder, la creciente brecha entre ricos y pobres, y las consecuencias endémicas que esto conlleva para la vida social, econónica y política de las naciones asiáticas.

4. En segundo lugar, existe el constante control de las economias de los parses asiáticos por parte de las potencias imperialistas, por ejemplo. Estados Unidos, principalmente mediante las operaciones del capital transnacional y la pene- 
tración creciente de las empresas mulinacionales.

5. La experiencia colonial fue variada en los distintos países asiálicos.

5.1. La mayor parte de estos países cayeron bajo el control políico direclo de alguna potencia occidental, como, por ejemplo, Indonesia, Malasia e India.

5.2. Otros, como Filipinas, pasaron por el sucesivo control y ocupación de dos potencias occidentales.

5.3. Todavía orros, como China, fueron "cortados como una sandía," aunque ninguna potencia en particular ejerciera un control total, sino que su territorio fue dividido entre varias potencias occidentales, tanto europeas como norteamericanas.

5.4. Y otros, como el caso de Corea, fueron colonizados por otros países asiáticos, como el Japón.

5.5. Solamente Japón y Tailandia no fueron nunca controlados o colonizados por potencia extranjera alguna.

6. En vista de la variedad de experiencias coloniales, los países asiáticos en el presente tienen economias neocoloniales, estructural y materialmente controladas y manipuladas por las superpotencias económicas.

6.1. Los países que han logrado el llamado "milagro económico," tales como Corea del Sur, Singapur, Hong Kong y Taiwán, poseen economías relativamente frágiles y muy dependientes de las fluctuaciones del mercado y el comercio intermacionales.

6.2. Hay países que viven bajo la sombra de una severa crisis de endeudamiento y que están sujetos a los dictados de las instituciones financieras intemacionales, tales como el Fondo Monetario Internacional y el Banco Mundial. Filipinas y Corea del Sur son ejemplos de países que sufren esta siluación.

6.3. La producción para la exportación es la tendencia que se observa en la mayoría de estos países, y las "zonas francas de maquila" han proliferado en muchos países con las consecuencias sociales y económicas generalmente adversas para la vida interna de estos países.

6.4. El nivel de desempleo es muy alto en algunos paises, al grado de que la exportación de mano de obra y la migración de obreros han sido muy elevadas tanto dentro de la región como hacia otras partes del mundo. Filipinas es uno de lo más grandes exportadores de mano de obra.

7. Como resulado de lodos estos factores, pocos países pueden proclamarse económicamente soberanos y menos países aún pueden mantener el crecimiento de la producción y la estabilidad económica sin depender de la ayuda y la "asistencia" de países más poderosos en otras partes del mundo.

7.1. En este sentido, Japón puede ser considerado como excepción. De hecho, se ha convertido en un país "semi-imperialista" extendiendo su ayuda tanto tecno- 
lógica como económica a otros paises; y en cierto modo ha logrado controlar economías de otros. El resto de Asia se ha convertido virtualmente en mercado para los intereses industriales y comerciales japoneses.

7.2 También China puede considerarse como excepción. Su organización de tipo socialista ha proporcionado los fundamentos estructurales y las bases materiales a una actividad económica relativamente autónoma y dependiente de sí misma

8. En tercer lugar, existe la situación generalizada de la exclusión de las masas de cualquier participación significativa en el proceso de toma de decisiones sobre la sociedad y las estructuras polílicas de la nación.

8.1. Existen países bajo regímenes democrático-liberales que, por lo tanto, mantienen una apariencia de gobiemo parlamentario, por ejemplo, Japón y la India

8.2. La tendencia generalizada y la caracteristica común de la región, sin embargo, la constiluye el surgimiento del "estado omnipotente," que ejerce un dominio centralizado y autoritario, frecuentemente apoyado por la hegemonía norteamericana y al servicio, en buena medida, de los intereses de las élites sociales, econónicas y políticas.

8.3 En muchos paises de la región operan formas del sistema del Estado de seguridad nacional, en los cuales las élites militares y tecnocráticas controlan el sistema político justificando su dominación en función de un rápido crecimiento y desarrollo económico.

8.4. El resultado es la perpetuación de la represión política en el interior de cada país y de los dictados imperialistas desde el exterior, de tal manera que el "espacio democrático" es precario y el logro de una supuesta independencia política es en buena medida una farsa. El autoritarismo, las estructuras políticas de opresión y dominación, la violación y restricción de los derechos humanos y la ausencia de intituciones políticas auténticamente democráticas, por medio de las cuales se pueda expresar la voluntad y soberanía popular, configuran las realidades políticas dominantes de la región.

9. En cuarto lugar, la militarización sigue siendo, en consecuencia, no sólo el modo de dominación política típica, sino también un modo de vida en la región.

9.1. Existen parses bajo gobierno militar directo, como, por ejemplo, Indonesia, Corea del Sur y Taiwan.

9.2. Hay países que supuestamente se han sacudido la "dominación militar," como Filipinas, pero el "espacio democrático" que se ha conseguido sigue siendo relativamente precario y frágil.

9.3 Los presupuestos militares se han incrementado en años recientes en casi todos los paises asiáticos.

9.4. El creciente predominio de los militares en cargos de poder político es un fenómeno común en la mayoría de los países asiáticos. 
9.5. De gran importancia para la región es el renacimiento del militarismo y el nacionalismo en Japon. De forma callada, Japon se ha rearmado, ha organizado un muy potente ejército y se ha dedicado a la fabricación de armamento militar. El resurgimiento de tradiciones imperialistas y militaristas en Japon se ha mostrado con fuerza en tiempos recientes.

10. Más allá de estas muy claras muestras de militarización se está dando, además, el proceso mediante el cual los valores, la ideología y los patrones de comportamiento militares continúan ejerciendo un influjo dominante en los asuntos políticos, sociales, económicos y de política exterma del estado. Este proceso se ha introducido no solamente en la vida política, sino también en las estructuras de la vida social, cultural y educacional de los paises asiáticos .Las violaciones de los derechos humanos, el sojuzgamiento de movimientos y organizaciones populares, la supresión de la disidencia y de la oposición, las capturas y hasta las ejecuciones sumarias, todo ello se ha convertido en el modus operandi convencional en la vida política de la mayoría de las sociedades asiáticas. Valores tales como obediencia, sumisión y "cooperación," predorninantes en el ethos militar están siendo inculcados de igual manera en la vida culural y educativa de las sociedades asiáticas.

11. Estas realidades socioeconómicas y políticas han exacerbado y aportado nuevos elementos a las raíces tradicionales del conflicto social, tales como la supresión de las minorías, la tensión entre grupos religiosos y las rivalidades entre lealıades érnicas y tribales en los países de la región.

12. Las semejanzas y las diferencias, en este aspecto, son muchas: la India tiene que enfrentarse a la creciente radicalización de los sikhs. Sri Lanka tiene que enfrentar el problema Sinhala y Tamil, que recientemente ha alcanzado altos grados de violencia. Filipinas enfrenta graves problemas debido a las fuertes demandas de autonomía y aun de separación por parte de grupos culturales minoritarios en el norte y de los musulmanes en el sur. Indonesia sigue enfrascada en el asunto de Timor. En Malasia existe el delicado asunto, de lipo racial, surgido del conflicto entre los componentes chino y malasio de su población. Incluso Japón, altamente industrializado, enfrenta problemas y tensiones internos, originados por el trato que se da a la población coreana minoritaria en el país.

13. Por úllimo, existen intensas rivalidades ideológicas y las rivalidades entre las superpotencias que se manifiestan de manera peculiar en la región asiática y dentro de cada uno de los paíeses.

13.1. En la región asiática existe un cordón de bases militares norteamericanas que se extienden desde el norte hasta el sur del área. Desde el Océano Pacífico hasta el Mar del Sur de China, y siguiendo al Océano Indico, estas bases militares han sido instaladas para crear un arco defensor del "mundo libre" contra la agresión del "mundo comunista."

13.2. La guerra de Viet Nam, una de las guerras más intensas en el período de la post-guerra, obtuvo para los soviéticos una firme cabeza de playa en la región 
del sudeste asiárico.

13.3. El "miedo al comunismo" es intenso en muchos países de la región, por ejemplo, en Filipinas, Corea del Sur e Indonesia.

13.4. El surgimiento de sociedades socialistas ha ocasionado divisiones políticas en buen número de pafses, como, por ejemplo, Corea, de modo que la cuestión de la división y la reunificación constituye una grave preocupación, con componentes ideológicos, así como políticos, sociales y económicos.

$13.5 \mathrm{El}$ "problema comunista" ha precipitado o contribuido a varias formas de golpes de Estado que han supuesto el "exterminio" de gran número de gente, como, por ejemplo, en Indonesia. En estos casos, los problemas y las animosidades ideológicas y étnicas han provocado una de las manifestaciones más violentas de conflictos políticos internos que se haya visto jamás.

13.6. En las Filipinas, se está librando una guerra popular con muy claros componentes ideológicos. La chispa de la insurgencia comunista sigue viva en muchos palses asiáticos.

13.7. El desafío de los modelos socialistas está presente en la región asiálica no solamente en teoria, sino en la existencia real de sociedades socialistas.

14. En medio de persistentes estrucuras de pobreza y dependencia económica, del desarrollo desigual dentro de y entre los varios países de la región, de la represión y dominación política, del conflicto ideológico y las incursiones foráneas, existen movimientos populares para la transformación social y el cambio político que han crecido, en grados e importancia variados, en diferentes parses. Estos movimientos constimyen también un elemento importante en el panorama socioeconómico y político de la región.

14.1. En los centros urbanos se dan luchas y movimientos obreros en busca de justicia y equidad. En grado diverso, prospera la lucha de los urabajadores en varios países asiáticos a pesar de los controles a que está sometida.

14.2. En las zonas rurales existen movimientos organizados de campesinos que también siguen creciendo y que buscan desmantelar los ancestrales sistemas de tenencia feudal de la tierra y exigen un mayor control sobre los frutos de su trabajo.

14.3 Existen también gupos religiosos organizados de cristianos y de otras fes, que se han solidarizado con los pobres y han expresado su compromiso con la lucha por la liberación.

14.4. Existe asimismo en varias sociedades una creciente conciencia y movilización entre las mujeres en contra de la injusticia a que son sometidas y en favor de una participación plena en la vida y la transformación del orden social.

14.5. Existen movimientos de minorías étnicas y culturales que cuestionan la injusticia y la inequidad de la socicdad que les rodea y en la que viven.

14.6 Existen movimientos organizados de los consumidores que apuntan a la 
más elemental de las violaciones de los derechos humanos, como es la privación de los productos y servicios básicos necesarios para la supervivencia

14.7. Existen movimientos de estudiantes y maestros que luchan por una mejor educación y más orientada a las masas populares, y por la emancipación de sus sociedades del control militarista, autocrático e imperialista.

14.8. Existen movimientos en favor del nacionalismo y en contra de la dominación extranjera en las diversas áreas de la vida social, económica, política y profesional.

14.9. Existen movimientos en contra de las armas nucleares y en favor de la paz y la independencia de la región.

14.10. Existen movimientos en favor de los derechos humanos y las libertades políticas y directamente en contra de la militarización.

14.11. Existen movimientos en favor de mantener el balance ecológico y ambiental que redundaría en un medio ambiente más saludable para el desarrollo humano y preservaria la inlegridad de la creación.

14.12. Por último, existen movimientos organizados para la liberación nacional, que, en algunos lugares, como Filipinas, llevan adelante una lucha armada, mientras que en otros se comprometen con varias formas de trabajo político para reafirmar la independencia nacional y la auténtica democratización y transformación de la vida económica, social y política.

15. En resumen, dentro de cieras realidades socioeconómicas y políticas comunes, existen divergencias en cada uno de los países de la región, producto de factores específicos de tipo histórico, cultural y otros. Sin embargo, es claro que dentro de eslas semejanzas y divergencias, la vida socioeconómica y polílica de la región está en una situación de gran tensión y descontento, nacidas de la realidad continua e intensificada de estructuras de dominación y represión, por un lado, y el auge y organización creciente de la lucha popular, por el otro. Dentro de este contex lo de tensión y contradicción debe ubicarse la reflexión teológica.

\section{B. Comparación con otras regiones del tercer mundo}

16. Las semejanzas y divergencias con otra regiones del tercer mundo aparecen, en lo general, obvias. Es común la experiencia del colonialismo y neocolonialismo, aunque las formas históricas especílicas que ha tomado en los diversos países y regiones puede ser distinta. Es común la realidad de la pobreza, pero los niveles y grados de disparidad entre ricos y pobres puede variar. El fenómeno de una importante potencia industrial y económica, como la de Japón en Asia, en interacción con sus vecinos, regionalizando las incursiones imperialistas, puede ser algo peculiar de Asia, aunque existen indicios de que algo semejante pueda estarse gestando en otras regiones también. El fenómeno de las ciudades-estado, que han logrado un notable progreso económico, es específico de la región asiálica. 
17. La permanencia y afianzamiento de sistemas políticos de represión, el Estado de seguridad nacional, por ejemplo, es común, aunque de nuevo pueden variar las formas concretas. La guerra del Vietnam y la guerra de Corea suponen conflictos militares que hasta ahora no han aparecido en toda su magnitud y consecuencias en las otras regiones. Los niveles y formas de la presencia militar directa de las potencias extranjeras, como Estados Unidos, varían considerablemente dentro de y entre las regiones del mundo. En Asia se da una considerable presencia de instalaciones y personal militar de Estados Unidos, situación que no se da en las otras regiones. Esto da lugar a ciertos problemas sociales, políticos y económicos que no se viven en aquellas regiones o países donde esta presencia militar no se hace sentir.

18. El problema ideológico del desafío socialista está presente en todas las regiones, pero la manifestación política peculiar de este problema, ejemplificado en la división de parses como Corea, es específico de Asia. El nivel de conflicto y confrontación militar que esto ha generado puede que haya sido más intenso en Asia que en cualquier otra parte. El componente religioso del conflicto social y político puede ser más importante en Asia que en otras regiones. El componente racial en el conflicto social y político está presente en Asia, aunque en general puede que no sea tan determinante como lo es en Africa del Sur.

\section{Realidades religioso-culturales}

\section{A. Asia}

19. Asia es el centro de algunas de las culturas más antiguas del mundo y la cuna de todas las grandes religiones mundiales. Estas religiones y muchas de las culturas wodavia existen hoy en día y ejercen una influencia activa en los parses asiálicos.

20. Las culiuras y las religiones se relacionan y se mezclan. Algunas religiones están presentes en muchas culturas. Algunas culturas se abren a varias religiones. La complejidad de la realidad religioso-cultural de Asia se refleja en la siguiente síntesis:

20.1. El budismo, el islam y el cristianismo, que son religiones misioneras, se encuentran en una diversidad de entomos culturales. El budismo, con sus raíces en el norte de la India, es la religión principal en Sri Lanka, Birmania, Tailandia, Laos, Campuchea y Vietnam, además de contar con numerosos seguidores en China, Corea y Japón. El islam se extendió desde el Asia occidental hacia Pakistán, Bangladesh, Malasia e Indonesia. El cristianismo se encuentra en la mayoría de los países de Asia en proporciones pequeñas; solamente en las Filipinas llega a ser la religión del 92 por ciento de la población.

20.2. El hinduismo se encuentra principalmente en la India y en lugares con población de origen indio. En la India existen creyentes que comparten una 
cultura general india, tales como los hindúes, los musulmanes, los sikhs, los cristianos y los jaines.

20.3. El confucionismo, el taoismo y el shintoísmo son las principales influencias filosoficas y religiosas entre los chinos, los japoneses y los coreanos.

20.4. Esta multiplicidad y superimposición de culturas y religiones es comprensible, por lo tanto, en un continente que representa aproximadamente el 58 por ciento de la raza humana y que tiene la más antigua tradición de religiones organizadas.

21. Asia también se caracteriza por la presencia de diversas razas, grupos élnicos, tribus y, en el caso del subcontinente indio, castas. Estos grupos frecuentemente se distinguen por sus características lingüísticas y culturales y a veces por su religión. Tienen sus propios intereses comunes y luchan por conservar su identidad, sus dercchos y sus privilegios. Muchos de los conflictos dentro de los países asiáticos son de naturaleza étuica, racial, tribal o de casta. Estos conflictos no pueden reducirse a puros intereses económicos, aunque los factores económicos tienen también un impacto vital. Los conflictos en la India entre hindúes y sikhs; en Sri Lanka, entre sinhala y tamiles, y por la autonomía de los moros en la Filipinas, tienen un carácter écnico en el transfondo de religiones diferentes.

22. A través de la milenaria historia asiática, las mujeres han sido tratadas como sexo inferior. Han sido explotadas en el hogar, en el trabajo y en la vida social. Esto es cierto en casi todos los grupos é́nicos y raciales, de todas las culturas y de todas las religiones.

23. En todos los países asiáticos existen religiones populares que han surgido entre los pueblos durante generaciones. Se basan en un esfuerzo por dominar lo desconocido y lo imponderable, y por dar sentido a los gozos y a las tragedias de la condición humana. Tienen que ver con enfermedades, el nacimiento y la muerte, los temores, los sueños, las rivalidades, los hechizos, los espiritus, la propiciación de los dioses, el clima, la buena y la mala fortuna, las cosechas, etc.

23.1. Estos cultos tienen sus seguidores y practicantes regulares, sacerdotes y encargados del ritual. El pueblo recurre a ellos para resolver sus necesidades y ha desarrollado elaborados rituales para ocasiones diversas; por ejemplo, el shamanismo en Corea.

23.2. Muchos aspectos de las religiones desarrolladas han sido influenciadas por las prácticas de estas rcligiones populares, por ejemplo, el caso del cristianismo popular en las Filipinas. Esto explica en parte por qué y cómo coexisten en el pueblo las diferentes religiones. Personas de todas las religiones rinden culto en ciertos santuarios porque éstos dan respuesta a sus necesidades religiosas en diversas circunstancias de la vida.

24. Las religiones mundiales organizadas, tales como el hindufsmo, el budismo, el cristianismo, el islam, y enfoques filos6fico-rcligiosos como el 
confucionismo, tienen una larga tradición de suministrar atención espiritual a los pueblos asiáticos.

25. Estas religiones ticnen sus propias escrituras sagradas que conticnen profundas reflexiones filosóficas así como ensenanzas sobre el desarrollo espiritual de las personas. Las escuelas filosólicas tienen su propio sistema de lógica y ofrecen explicaciones sobre la vida y el destino humano en relación con los valores transcendentales de Dios y/o de la realización espiritual. Escrilos como los Vedas y los Upanishads provienen de tiempos muy antiguos y han sido transmitidos y comentados por varias generaciones de videntes ilustrados. Incluyen las palabras de Buda, Confucio, Lao Tse, la Biblia y el Corán.

26. Las religiones tienen sus grandes fundadores como Buda, Jesús y Mahoma, quienes fucron grandes relormadores religiosos y profetas en su día y, después, para las generaciones sucesivas. En tiempos más recientes han surgido otros grandes dirigentes espirituales, el más conocido de los cuales es Mahatma Gandhi.

27. Las religiones asiálicas tienen una tradición tanto de investigación endila como de misticismo. En toas las rcligiones se recalca la purificación personal y la liberación interior.

27.1. El budismo y el hinduísmo enfatizan la realización personal a través de la meditación y de las buenas obras dentro de un ciclo de nacimiento, mucre y reencarnación en varias vidas.

27.2. En el hinduísmo existe una tradición subyacente de unión con Dios el Absoluto, quien es considerado como el origen de todo ser, de toda bondad y de toda verdad.

27.3. La ética del confucionismo destaca la conducta correcta y la sinceridad y honestidad en la vida personal y pública.

27.4. El cristianismo y el islam se preocupan más por la vida humana en comunidad y enseñan que la salvación etema depende de la vida presente de cada uno aquí en este mundo.

28. Las religiones asiáticas tienen en común un núcleo humanizante de enseñanzas que se refieren a la vida personal, moral y social. Todas recalcan el valor y la necesidad del desprendimiento y desapego de las cosas materiales. Enseñan la compasión, la preocupación por el otro, el compartir las posesiones, el amor a la familia, el respeto a los mayores, el cuidado de la naturalcza, y la conducta correcta en la vida pública y privada. Todo ello ofrece la oportunidad de auto-purificación y de servicio a los seres humanos que sufren necesidad. Este núcleo de valores comunes puede sentar las bases para la liberación humana integral y para la cooperación en la construcción de comunidades en nuestras sociedades plurales de Asia. Al trabajar por los intereses humanos comunes, las comunidades humanas de base o grupos de acción pueden resolver los problemas tal como se presentan en la sociedad. 
29. El impacto de los factores religioso-culturales es notable en Asia. Si bien es cierto que las motivaciones básicas de las religiones y culturas asiáticas son de liberación y de interés por el prójimo, también existen en estas religiones y culturas aspectos perniciosos y esclavizantes.

29.1. Pueden conducir a las personas y a los grupos al egoísmo y a un comunitarismo estrecho, sean estos grupos de naturaleza cultural, religiosa, lingüística, étnica, tribal o de casta. Los otros pueden ser considerados extraffos y hasta competidores y enemigos. Prejuicios culturales, estereotipos y mitos refuerzan tales actitudes estrechas y chauvinistas.

29.2. En lo que se refiere a las relaciones entre los sexos, las religiones continenen aspectos tanto liberadores como opresivos. En todas las religiones existe una cierta comprensión de que tanto el varón como la mujer participan en la vida del Absoluto o de que son capaces de la auto-realización última. Sin embargo, todas las religiones tienen actitudes discriminatorias hacia la mujer. En la mayoría de las religiones se las priva de ejercer roles, de tomar decisiones, y de participar en el sacerdocio.

29.3. Las religiones influencian la psicología de los pueblos. Algunas de ellas estimulan la actividad humana hacia la transformación del universo. Pero por lo general promueven una actitud pasiva y fatalista hacia la naturaleza y el desarrollo, la vida y la muerte, las relaciones y estructuras sociales. Tienen la tendencia a formar a las generaciones sucesivas en actitudes de conformismo y subordinación a los poderes existentes ya sean éstos feudales, capitalistas, coloniales o neocoloniales. Esto puede conducir a la legitimación de los poderes político, social y económico, y a la dominación del varón.

29.4. Las culturas asiácicas han sido poderosos medios para perpetuar las relaciones y estructuras de opresión en la sociedad al ocasionar una interiorización de la conciencia de inferioridad y debilidad en el sexo, castas, tribus y grupos étnicos dominados. La conciencia colectiva tanto de los dominadores como de los dominados es, por lo tanto, reforzada y transmitida de generación en generación de tal manera que la opresión aparece legitimada aun dentro del grupo de los oprimidos. Una liberación integral requiere una psicoterapia personal y de grupo para liberarse de tales inhibiciones, temores y mitos.

29.5. Las religiones han sido una poderosa crítica de la injusticia, la desigualdad, la comupción y el autoritarismo. Las religiones producen también una cultura de protesta y de resistencia contra tales abusos, como pudo apreciarse en el movimiento independentista en la India encabezado por Mahatma Gandhi, en la revolución iraní encabezada por el Ayatola Khomeini, en las luchas por los derechos humanos en Corea del Sur y, más recientemente, en las acciones de protesta del pueblo filipino en contra de Marcos.

30. Debido al influjo de la ciencia modema y de la tecnología, así como a la unificación del comercio mundial, los viajes y el flujo de las comunicaciones, pueden apreciarse ciertas tendencias en las culuras y las religiones del Asia que 
apuntan hacia:

a. una modernización de los patrones de vida, de las prácticas y las relaciones dentro de la familia y la sociedad;

b. un fundamentalismo que lleva a que las culturas y las religiones se enciemen en sí mismas, y a la defensa de los privilegios de unos en contra de los otros; incluso, a atacar a otras religiones y culturas;

c. una renovación de las religiones mediante el estudio científico de sus orígenes y un retomo a las mejores inspiraciones que contribuyeron a su fundación; apenura a otras culturas junto al desarrollo de lo bueno en la propia;

d. un ecumenismo entre distintas fes que trasciende limitaciones de doctrina y que lleva al diálogo en tomo a los valores básicos y a las inspiraciones fundamentales, contribuyendo asi, poderosamente, a la liberación humana integral y a la realización de los individuos y los pueblos.

31. Hay que abordar la relación entre ideologlas y religiones asiáticas. Los estados asiáticos afrontan de manera diferente las religiones y las culuras asiáticas.

31.1. Aquellos que son capitalistas y promueven la iniciativa privada estimulan la libertad religiosa, pero tratan de ganarse a las diversas religiones para que apoyen el sistema de valores propio del capitalismo. Estos paises están abiertos a los influjos culturales de afuera, especialmente de los paises ricos occidentales. El consumismo se expande a través del comercio, la ayuda económica,la educación y las políticas desarrollistas. Todo esto tienen efectos buenos y malos. Entre estos hay que señalar abusos tales como la drogadicción, la prostitución, la corrupción y el indeseable influjo de los medios masivos de comunicación. Las religiones generalmente terminan siendo compradas, al ofrecerles libertad y las ventajas materiales del sistema.

31.2. Los estados socialistas bajo regímenes marxistas se opusieron inicialmente a las religiones $e$ incluso las persiguieron. Intentaron producir una contracultura diferente de los valores conservadores tradicionales, en el caso del confucionismo en China, y de los modernos estilos de vida del occidente. Pero recientemente se han mostrado más tolerantes con las religiones y se están abriendo a la cultura moderna de los paŕses industrializados, siendo China ejemplo de este proceso.

31.3. Algunos estados, como la India, han adoptado una filosofia más secular sin aceptar una religión estatal. Otros, como Pakistán e Irán, han implantado el islam como religión oficial. Ambos enfrentan diferentes tipos de problemas al tratar de satisfacer las demandas de los grupos culturales y religiosos, mayoritarios y minoritarios, dentro de sus respectivos países.

31.4. Las potencias mundiales, por su impacto en los asuntos económicos, polílicos y militares, ejercen tambiên su influjo en las culturas e incluso en las 
actitudes religiosas de los pueblos asiáticos.

32. Las religiones y culturas asiálicas son realidades sociales complejas que se toman problemáticas para sus pueblos en la medida en que se abren al mundo moderno. De igual manera representan una problemática profunda para la reflexión teológica cristiana.

\section{B. Comparación con otras regiones del tercer mundo}

33. En las sociedades africanas y asíticas, la cultura juega un papel predominante en la formación de la comunidad, en la configuración de la personalidad y en proporcionar continuidad entre el pasado y el futuro. La sociedad africana pone mayor énfasis en el proceso de iniciación, en el papel de la danza en las celebraciones comunales y en el respeto a los antepasados. Sin embargo, también el Asia oriental muestra respeto a los antepasados en las tradiciones religiosas del confucionismo.

34. Una semejanza compartida por los tres continentes se da en el hecho de que fueron invadidos y colonizados por las potencias occidentales y de que sus culturas fueron alacadas o despreciadas.

34.1. En América Latina, el ataque a las cularas llevó a que las culturas autóctonas desapareciesen casi por completo de la vida pública. Se dio una imposición de la cultura, el lenguaje y el catolicismo de Espafia y Portugal sobre los pueblos nativos que sobrevivieron a la espada de los conquistadores. Un proceso similar ocurrio en las Filipinas.

34.2 En Africa la cultura ha sobrevivido, por lo general, y se ha reafirmado desde que se independizó políticamente de sus colonizadores. Las culturas autóctonas, marginadas con la llegada de las religiones mundiales organizadas, como el cristianismo y el islam, están ahora reviviendo, se están renovando y revalorizando.

34.3. En Asia las culturas y las religiones padecieron mucha humillación, pero han sobrevivido al ataque de los occidentales. Sin embargo, las culturas manifiestan las huellas del reflejo que ha ejercido la modernización y la occidentalización. En las Filipinas el cristianismo ha influido en el modo de vida de la gran mayoría de la población -excepción hecha de las minorías culturales y all donde el islam era la religión establecida, como el caso de los moros.

35. En Asia están todas las grandes religiones mundiales. De estas religiones mundiales, en Africa está principalmente el islam y el cristianismo, mientras que América Latina es casi exclusivamente cristiana

36. Las religiones asiáticas tienen una larga tradición de escritos sagrados mientras que Africa tiene fundamentalmente una tradición oral, exceptuando el norte. En Amércia Latina la actual tradición escrita proviene de Europa occidental.

37. Africa, Asia y las antiguas religiones autoctonas de América del Sur creen 
en un ser supremo trascendente, con la notable excepción del budismo theravada.

38. En los tres continentes, el cristianismo ha sido considerado como una religión foránea. Llegó al Asia en los albores de la era cristiana, arribó después al continente africano y mucho más tarde, en el siglo $\mathrm{XV}$, se hizo presente en América Latina.

39. En los tres continentes todas las demás religiones fueron atacadas por los cristianos como "paganas." En América Latina y en Africa las religiones autoctonas han sido casi completamente marginadas y despreciadas, llegando hasta el punto de desaparecer en muchos lugares. El islam logró conservar sus avances y se extiende actualmente en Africa. En Asia, a pesar de los intentos de los misioneros por establecer el cristianismo, las otras religiones mundiales han conservado su predominio. Los cristianos siguen siendo una minoria de menos del 3 por ciento, con la excepción de las Filipinas.

40. La dominación de las mujeres por los hombres ha sido una constante universal en los tres continentes. Sólo en años recientes han surgido movimientos de emancipación femenina cuyo impacto gradual se ha dejado sentir en los tres continentes. Las sociedades de tipo socialisla se han mostrado más conscientes de la igualdad de los hombres y las mujeres. China, bajo el gobierno de Moo, llevó a cabo reformas muy amplias en favor de la igualdad y la dignidad de la mujer.

\section{III.Problemasteológicosquesurgendelasrealidadessocioeconó- micas, políticas y religioso-culturales.}

\section{A. Asia}

41. Una coología del cambio social, en general, y de la lucha, en particular, debiera tratar los siguientes puntos:

a el significado de la lucha como medio para lograr el cambio social y polf́ico, y como instrumento crílico para llevar a acabo una purificación y renovación de la reflexión teológica y de la espiritualidad cristiana;

b. el significado religioso y teológico de la afirmación de que el pueblo, los pobres o los oprimidos, son los sujelos del cambio social y político, así como el significado de la solidaridad cristiana;

c. dónde y en qué forma encontramos o localizamos la presencia de Dios en la actual lucha por el cambio social, económico y político;

d. las diversas formas de lucha y la teología ética de la violencia y de la no violencia;

e. qué significado tendria lo anterior para la acción pastoral de la Iglesia y para la vida cristiana.

42. El problema de una nueva hermenéutica de la tradición cristiana y de la 
Biblia a la luz de una nueva hermenéutica de nuestra historia actual:

a cómo y de qué manera descubrimos al "pueblo" como sujeto de la historia;

b. cómo releemos y reinterpretamos las narraciones brblicas y toda la historia de la tradición y de la misión cristiana de tal manera que descubramos las dimensiones liberadoras y transformadoras de la fe.

43. El problema de una nueva comprensión de la soberanía del pueblo, lo cual suscita las siguientes cuestiones:

a. La democratización de la vida social, econónica y política;

b. el estar a cargo de la creación de Dios y la redistribución de la propiedad y de los frutos de la producción;

c. la crílica del imperialismo y de las relaciones neocoloniales.

44. El problema de la teología y la ideología que trataría los siguientes punlos:

a un examen crítico del significado de la ideología y de las opciones ideológicas que puedan tomar los cristianos;

b. un reconocimiento crítico de la función ideológica de la teología como legitimación y racionalización del actual orden y del poder en la sociedad;

c. un descubrimiento positivo del papel de la teología como disciplina crítica de reflexión en tomo a la praxis liberadora y transformadora en el presente.

45. El problema de la espiritualidad cristiana y de la justicia que incluiría los siguientes puntos:

a. el contenido social y político de la espiritualidad;

b. el descubrimiento y la introyección de las dimensiones liberadoras y transformadoras de la espiritualidad y religiosidad "popular."

46. El problema de la eclesiología que debería atender los siguientes puntos:

a. la transformación de la Iglesia de tal manera que esté al servicio de la lucha por la liberación y la transformación social en vez de obstaculizarlas;

b. la configuración, estructura, liderazgo y papel de una Iglesia transformada en una sociedad tranformada; la configuración social y política de la Iglesia en el futuro;

c. cómo abordar la gracia, la espiritualidad y el poder dentro de la Iglesia.

47. Finalmente, una pregunta cristológica clave, ¿quićn es Jesucristo para quienes están comprometidos con la lucha política y social, y que significa para ellos y para nosotros creer en él?

48. En resumen, la tarea teológica en relación a la realidad político-económica de Asia tiene que ver con la articulación del cómo y de qué manera la lucha popular por la liberación y la transformación social se encuentra y coincide con el plan de Dios. Tal articulación se convierte en "principio" crítico desde el cual se 
evalúa la vida de la Iglesia, incluida su comprensión "tradicional" de la teología y la espiritualidad. Tal articulación serviria, además para esclarecer crílicamente el problema de quién hace teología y con qué finalidad, y para redefinir el significado de la praxis y la acción pasloral cristiana en el mundo.

49. En relación a las culturas asiáticas, hay que tratar los siguientes puntos:

a. una crítica de las culturas, distinguiendo los aspectos liberadores y opresores de cada una;

b. el grado y las formas de inculturación: en el lenguaje, el arte, la música, la arquitectura; en las formas de vida, la identificación con los pobres; en la relación de la cultura con la lucha de los oprimidos hacia su liberación y su auto-realización; en la transformación de las relaciones de dominio del varón por otras de colaboración y participación; en la ayuda a resolver conflictos étnicos y culturales, trascendiendo el comunitarismo limitante (es decir, la lealtad a una agrupación sociopolíca en base a la afiliación religiosa).

50. Los problemas teológicos que surgen de la relación del cristianismo con otras religiones incluyen los siguientes puntos:

a. la apertura hacia y la tolerancia de otras religiones;

b. la aceptación de las otras religiones y el trabajo conjunto con ellas en la formación de comunidades;

c. la expresión de la revelación cristiana en y a través de los conceplos filosóficos y religiosos de los pueblos y de las religiones asiáticas;

d. el trabajo de purificación del cristianismo y de las otras religiones de modo que todas pueden participar en la lucha por la liberación humana en Asia; la unificación de los elementos positivos liberadores de las religiones;

e. el replanteamiento del concepto cristiano de revelación: hasta qué punto y de qué manera puede estar Dios comunicando un mensaje a los pueblos asiáticos a través de las otras religiones - a través de sus fundadores, sus dirigentes, sus escrituras; el papel de la Biblia les normativo, definitivo, único, universal?; la relectura de la Biblia desde esta perspectiva;

f. la comprensión del pecado, la redención y la gracia (soteriología) y el papel de Jesús el Cristo en el plan divino de salvación-liberación;

g. los problemas de la cristología en el contexto de las otras religiones: Limpide la divinidad de Jesús que Dios se manifieste en otras encamaciones de lo divino?;

h. una evaluación de las formas tradicionales de la teología occidental: ¿hasta qué punto son universales o están atadas a una cultura?;

i. una comprensión del reino de Dios, de la Iglesia y de su misión en los países asiáticos en relación con otras religiones; que nuestra teología se 
centre en Dios y en el ser humano más bien que en la Iglesia; la autoridad de la Iglesia y su relación con la tarea de construir la comunidad de acuerdo a los valores del reino de Dios que escapan a su control.

51. La practica de la teología en Asia dentro de sus realidades culturales y religiosas enfrenta los siguientes retos:

a. la purificación de la teología cristiana;

b. relacionar los elementos medulares del evangelio de Jesús con los valores medulares de otras religiones e ideologías;

c. la participación en la construcción de las relaciones y comunidades humanas en la verdad, el amor, la justicia y la paz;

d. el desarrollo de una espiritualidad de compromiso y contemplación del Dios Unico junto con todos aquellos que se inspiran en las escuelas y prácticas de espiritualidad tradicionales; la liberación interior y la necesidad de una psicoterapia social que pueda sanar el dafio infligido a la psique colectiva.

52. Hay que abordar los siguientes puntos en relación a la problemática de los sexos:

a. una relectura de la Biblia desde una perspectiva de la mujer; y, según, esio, un replanteamiento del mensaje de Jesús y de la cristología;

b. una crítica de las prácticas y enseñanzas de la Iglesia por lo que toca a las relaciones mujeres-varones dentro de la Iglesia, especialmente en lo concerniente al ministerio, autoridad, liturgia, etc.;

c. las cuestiones en tomo a la moralidad, la sexualidad, la biogenética, el control sobre la vida humana, el cuerpo humano;

d. la cooperación entre las mujeres de distintas religiones para la purificación, en todas las religiones, del sexismo y sus consecuencias.

\section{B. Comparación con otras regiones del tercer mundo}

53. En comparación con otras regiones del tercer mundo, percibimos las siguientes semejanzas y divergencias:

53.1. En Africa, al igual que en Asia, sc ha manifestado una tendencia general en la teología cristiana a no dar consideración adccuada a las religiones locales. En el mejor de los casos se las ha considerado como complementarias a la revelación bíblica de los judíos, y después, tal como las entendieron los cristianos. Como en el caso de Asia, hubo incluso una depreciación de los valores, costumbres y rituales locales.

53.2. Sin embargo, en la actualidad la reflexión teológica está comenzando a cuestionar tales actitudes. Algunos escritores africanos suscitan preguntas semejantes a las que aparecen en algunos escritos asiáticos. Las preguntas se refieren a la especificidad y universalidad de la Biblia y a la posibilidad de la revelación de 
Dios a diferentes pueblos africanos. Desde ahf surgen preguntas en torno a la crisblogía, la personalidad de Jesús, la naturaleza y misión de la Iglesia, el significado y las consecuencias de la conversión al cristianismo, etc. En todo esto, están apareciendo semejanzas en Africa y Asia por lo que toca al cuestionamiento y elaboración teológicos

53.3. El auge de iglesias africanas independientes es una indicación de que las iglesias institucionales se han quedado cortas en responder a muchas de las preguntas planteadas por la sociedad africana, tales como la explicación de los suef́os, la enfermedad, la poligamia, la aceplación de la danza y la participación del pueblo en la liturgia. Estos aspectos no son predominantes en el caso de Asia.

54. Las respuestas teológicas africanas se han dado en dos direcciones principales durante la última década

54.1. En aquellos países independientes el énfasis se pone en la relación de la teología cristiana con la cultura africana, con las religiones y la religiosidad africanas y con la espiritualidad africana. Están emergiendo nuevas y radicales formas de pensar. Los teólogos cristianos están planteando el problema de qué signifíca que un hombre o mujer africanos se conviertan en discípulos de Cristo. En lodo esto pasan a primer plano los problemas relacionados con el contenido integral de la teología, la naturaleza del trabajo misionero, las enseñanzas acerca de la vida moral y el papel de la Iglesia.

54.2. En Africa del Sur el énfasis aclual se pone en la liberación del opresor régimen blanco que continúa explotando a los negros y a la región. La teología africana ya está en marcha y es probable que sea muy fructífera durante la próxima década.

55. En las últimas décadas América Latina ha experimentado un florecimiento de la teología. Comenzó con un análisis y una crítica de la sociedad y la elaboración de la liberación social desde un punto de vista cristiano. A esto acompafió una relectura de la Biblia desde la perspectiva de los pobres, el desarrollo de un método de hacer teología en relación al compromiso de transformación social. Durante este proceso se dió un replanteamiendo del papel y de la misión de la Iglesia y de la espiritualidad cristiana en relación con su misión social de liberación humana. La emergente teología de lucha en las Filipinas contiene muchos elementos semejantes.

56. En años recientes los teólogos latinoamericanos se han hecho más conscientes del movimiento feminista, de la presión de la población negra en América Latina y de la cultura y la religiosidad de los pueblos autóctonos de estas regiones. Todo ello está apenas en los comienzos. En la medida en que avanza, es probable que conduzca a una mutua fecundación de la teología latinoamericana y de las teologías africana y asiática.

57. En todos estos continentes, la reflexión teológica necesita ser complementada con un estudio amplio y estratégico del capitalismo mundial, de los 
parses socialistas y de la dirección de las iglesias como un todo. El enfoque continental, tal como es usado por lo general, puede que no aclare adecuadamente las dimensiones globales de los retos contemporáneos para los pueblos del tercer mundo y su actual práctica teológica.

\section{Metodologias comunes y divergentes de Eatwot}

58. La metodología es algo central para la teología. En todo quehacer teológico se adopta una metodología, ya sea de manera explícita o implicíta. Esto supone abordar los siguientes problemas: las fuentes de la teología; los supuestos presupuestos en el quehacer teológico; el contex to y las perspectivas desde las que se hace teología; el sujeto o la persona que hace teología; el proceso o la forma de hacer teología; el medio por el cual se expresa la propia teología; el contenido de la teología; las consecuencias de diferentes metodologías y su contribución al desarrollo de la teología. Solamente se analizarán algunos de los aspectos aquí mencionados en relación a las metodologlas que se describen en esta sección.

59. Esta sección tratará, primero, sobre la metodología general, haciendo referencia a otras regiones; después ofrecerá una breve descripción de cuatro metodologías actualmente en boga, que se están desarrollando en el contexto asiáLico.

60. En la mayoría de los casos, los tólogos de Asia aceptan lo que es valioso en los avances fundamenteles realizados ya por la teología de la liberación, es decir, lo que se refiere a los cristianos comprometidos como sujetos que elaboran teología, al compromiso como el primer acto de la teología, al análisis social como un indicador de los signos de los tiempos, al proceso de la elaboración de la teología como acción-reflexión-acción, al modo de expresar la teología también a través de las artes, y a la espiritualidad del compromiso con la liberación humana integral.

\section{A. Metodología histórico-contextual en referencia a las regiones africanas y latinoamericanas}

61. Las metodologías teológicas son formas de hacer teología sobre bases y fuentes bfblicas en relación a contexlos históricos, es decir, como compromiso con o respuesta a las luchas de los pueblos oprimidos del tercer mundo. Dos cosas dirigen la metodología histórico-contextual fundamental, que es común a las teologías de EATWOT: (1) puntos de partida y temas histórico-contextuales y (2) problemas de fundamentación bíblico-cristológica. Es decir, el problema de relacionar los textos bíblicos y los respectivos contextos.

62. El principio metodológico del modo histórico-contextual de hacer tcología ya está presente, implícita o explícitamente, en la teología europea moderna. Sin embargo, la especificidad y el carácter revolucionario de las teologías de EATWOT radica en la hecho de sus específicos puntos de partida históricocontextuales y su opción en favor de los pobres del tercer mundo (y de Estados 
Unidos) junto con los temas que surgen de la crítica a la dominación y tradición eclesio-teológica y cultural de occidente.

63. Los puntos de partida y los temas tratados requieren una transformación radical de la estructura de dominación occidental que está en contradición con la justicia y el reino de Dios. Las teologias de EATWOT, por lo tanto, poseen un carácter histórico específico y, sin embargo, a la vez, un significado universal.

64. A pesar de que los contextos de nuestros tres continentes divergen en lo histórico, lo religioso-cultural y lo étnico, todas estas realidades divergentes coexisten dentro de un destino común, la dominación del capitalismo occidental y moderno, y, por lo tanto, tienen en común el tema de la liberación. Este es el tema contextual común de las ideologías de EAWOT, lo cual es sumamente notable.

65. Sin embargo, EAWOT no ha explorado todavia el pencar, los milos y símbolos religioso-culturales, en cuanto divergentes, de otras fes en los tres continentes, relacionándolos con el tema común de la liberación. Falta todavía una metodología coherente para llevar a cabo esta comparación. Existen todavía divergencias en el modo de interpretar lo anterior desde posturas teológicas y perspectivas biblicas, que aún no han sido investigadas.

66. Por otra parte, no es claro que lodos los miembros de EATWOT estén de acuerdo o en desacuerdo respecto a la dirección y la forma de liberación políica y socioeconómica. Dados los puntos de partida comunes y la común temática de liberación, se pueden seftalar otras semejanzas y divergencias en tomo a problemas y preocupaciones en común. Las semejanzas y las divergencias existen no sólo entre los tres continentes, sino dentro de cada continente y aun entre los mismos miembros de EATWOT.

67. En el quehacer teológico se ha utilizado el análisis marxista, político y socioeconómico.

67.1. La toologia lauinoamericana de la liberación ha sido ejemplar en el uso del análisis socio-económico político y de la crítica manxista a la estructura mundial capitalista que es, hoy por hoy, el instrumento más importante de dominación y opresión. Se ha discutido positivamente el marxismo en su relación con el cristianismo de occidente, pero, aun así, las discusiones y evaluciones positivas siguen siendo ineficaces dentro de occidente.

67.2. Los mismos pueblos del tercer mundo, los pobres y los oprimidos, los minjung. los negros y las mujeres, las victimas de las potencias capitalistas dominantes, son los que poseen también, dentro de ellos mismos, la dinámica de la revolución y la liberación. El marxismo es quizás su mejor instrumento para lograr su liberación y hacer una revolución que encamine hacia un nuevo orden mundial, justo y humano.

67.3. El análisis socioeconómico del marxismo y su influencia es lambién presupuesto de varios movimientos y luchas del pueblo africano y, en mayor grado, del pueblo asiático contra la dominación occidental y japonesa. 
67.4. En lo que se refiere a China y Corea del Norte, el marxismo se ha convertido en parte integral de sus contextos sociales, aunque la teologia asiática no ha dado cuenta de ello, todavia, de forma significativa.

68.1. Dos problemas comunes deben destacarse. No se sabe todavia hasta qué punto los integrantes de EATWOT están de acuerdo sobre la validez de los elementos marxistas y si los aceptan como presupuestos para llevar adelante lo que EATWOT pretende. Si no se esclarece este punto, no será posible, en este sentido preciso, identificar las semejanzas y las divergencias entre los tres continentes. Los contextos de las preocupaciones de los pueblos son divergentes y complicados en si mismos. Aquf sólo podernos planteamos dos preguntas específicas. En primer lugar, cómo se puede relacionar significativamente el interés africano por la antropología-cosmología africana con el análisis y la crítica socioeconómica manista en favor de una nueva sociedad y un mundo nuevo. En segundo lugar, cómo se puede relacionar la herencia religioso-cultural de Asia con el problema de la liberación socioeconómica de los pueblos. Estas cuestiones tienen que ser investigadas y esclarecidas.

68.2. El uso del maxismo implica una opción política para el futuro en favor de un orden socialista. Sin embargo, este asunto no ha sido aclarado entre los miembros de EATWOT. En todo caso, aun presuponiendo tal opción, existen cierlos puntos que deben ser mencionados. La apropiación cristiana del socialismo o del comunismo marxista implica algo aś como una "tercera vía" más allá de los mundos divididos, los sistemas capilalista y socialista, tal como existen hoy en dia. Una "tercera vía" no significa la línea del Partido Demócrata Cristiano en Chile o en otros paises, oscilante entre los dos extremos, pero que, a la postre, siempre acaba integrándose en la cultura y en el cristianismo occidentales. Una "tercera vía" apunta hacia la última fundamentación y fuente de la liberación de los pueblos oprimidos, fundamentación y fuente que es el mismo Dios, quien no se identifica ni con el capitalismo ni con el socialismo como tales, aunque éste último pueda ser medio para superar al primero.

Una tercera vía debe entenderse como una superación del occidente capitalista y de la cristiandad, interpretando el marxismo teológicamente en el horizonte de una reconciliación escatológica de todo el mundo y la llegada del reino de Dios.

69. La dominación occidental de los pueblos de razas no-blancas, la esclavitud de los negros y el genocidio de los indígenas en el pasado, son los crímenes históricos del racismo blanco, al que han estado ligados el cristianismo occidental y el trabajo misionero. Si bien es cierto que las razas oprimidas se encuentran prisioneras de la modema dominación capitalista, el racismo es una forma de opresión más profunda y antigua que lo socioeconómico. Quizás lo racial es elemento revolucionario más poderoso que la liberación socioeconómica en los movimientos de liberación africanos. Hay que abordar el problema del racismo en conjunción con el de la dominación sociocconómica por parte de los blancos.

70. La herencia religioso-cultural de los pueblos del tercer mundo que tienen 
otras religiones es también otro factor contextual que debe ser tenido en cuenta teológicamente en favor de la liberación de los pueblos. Esta herencia incluye en sí misma elementos que son opresores, conflictivos y excluyentes. Sin embargo, es como el sello de la existencia que perdura y de la identidad espiritual de los pueblos. También esta herencia se encuentra inmersa en las fuerzas del capitalismo, pero, aun asi, es una dimensión distinta de la socioeconómica.

71. Las teologías del tercer mundo pueden aprovechar esta herencia para elaborar un nuevo lenguaje teológico, siempre y cuando sean reinterpretadas sobre bases bíblico-teológicas. En otras palabras, la experiencia de la presencia y de la acción de Dios dentro de los coniexios histónicos religioso-culuurales puede ser articulada en sus propias lenguas, simbolos, mitos e imágenes, al servicio de los pueblos en lucha y al servicio de sus movimientos de liberación.

72. Para que las tradiciones religioso-culturales heredadas se conviertan en lenguajes liberadores, deben ser reinterpretadas y reubicadas crítcamente en relación con sus propios problemas y limitaciones históricas y con los problemas políticos y socioeconómicos del tercer mundo. De lo contrario, se toman ahistoricas en el sentido de que siguen existiendo desvinculadas de sus contexlos y problemas históricos, y hasta se toman antihistóricas al ejercer una función ideológica en favor de las estructuras de poder, capitalistas y opresoras.

73. Conviene indicar cuatro líneas de interprelación y de problemas,

73.1. El pensamiento e imágenes religioso-culturales de Asia, así como sus mitos y sus símbolos, contienen elementos espirituales diferentes a los de la espiritualidad cristiana occidental y más ricos que ésta en su penetración en la dimensión espiritual de la naturaleza humana y cósmica, hoy en día mayormente perdida bajo la influencia de la espiritualidad materialista agresiva de occidente. Por el contrario, la espiritualidad de otras tradiciones religiosas ha resurgido con frecuencia como parte de movimientos liberadores nacionalistas del tipo minjung. Sin embargo, el problema de estas espiritualidades radica en el hecho de que, por lo general, siguen estando desvinculadas de cicros problemas políticos y socioeconómicos, como si fueran espiritualidades transhistóricas o ahistóricas. Tienen que ser reinterpretadas, por tanto, dentro de sus contextos políticos y socioeconómicos, históricos y contemporáneos, y de las luchas de los pueblos por su liberación, por un lado, y a la luz de la fe bíblica en el Espíritu Santo, por el otro.

73.2. Otrás religiones, espíritus e imágenes cósmico-humanas pueden integrarse en la espiritualidad y en las formas del culto cristiano, si son reinterpretados desde la fe bíblica en el Espíritu Santo. No son idénticas al Espíritu, pero pueden interpretarse creaturalmente como espiritualidades. Los espíritus y las imágenes, o los milos y los símbolos, entendidos a la luz de la libertad del Espíritu Santo, pueden ser evocados dentro de las acciones simbólicas de liberación de los pueblos oprimidos, como por ejemplo en las danzas de los indígenas americanos contra los blancos, o también en el caso de los shamanes. Sin em- 
bargo, a menos de que se ubiquen en los contextos políticos y socioeconómicos actuales, los espíritus y las imágenes, o los mitos y los símbolos, no pueden convertirse en lenguajes de liberación de los pueblos que se encuentran oprimidos política y socioeconómicamente.

73.3. Una teologia hollstica, corno la que se descuella en el sur de Asia, apunta hacia una síntesis de la tolalidad de las espiritualidades religioso-culturales, tanto del cristianismo como de otras fes, es decir, una visión de totalidad espiritual transcendental humano-cósmica. Su intención es semejante a la de la teología de la religión-cultura, tal como acaece en Corea. Podemos suponer la misma tendencia teológica en los contextos religioso-culurales de China Un peligro inherente a este anhelo y esfuerzo por lograr una visión holística consiste en hacer abstracción de la problemática y de las peculiaridades históricas connictivas de las religiones, de los problemas políticos y socioeconómicos y de la culpabilidad humana, frente a todo lo cual se derrumba cualquier visión holística de la espiritualidad y del pensamiento religioso. Toda religión ansía llegar a una visión y espiritualidad holística, pero se derrumba ante los procesos históricos. Ciertamente, la totalidad abarcadora de las espiritualidades religiosas podrá llegara ser una realidad, escatológicamente, por obra del Espíritu Santo de Dios en la persona de Jesucristo. Pero, en la historia, cualquier espiritualidad religiosa debe ser probada en su relación con la vida, los problemas y las luchas socioeconómicas de los pueblos, en vista al perfeccionamiento de la realidad y el orden material. De hecho, profundas espiritualidades religiosas asiáticas se han mostrado impotentes ante el colonialismo y el capitalismo de occidente. Los fracasos y la culpabilidad de las diversas espiritualidades de las religiones, tanto de las cristianas como de las no cristianas, africanas y asiáticas, tienen que evaluarse según su relación con los problemas histórico-contextuales, y sus críticas, sometiéndose así al juicio divino por lo que toca a lo que ofrecen de salvación y de totalidad.

73.4. La práctica de la pobreza religiosa mediante la renuncia a las posesiones materiales, que se da en las religiones asiáticas, especialmente en el hinduísmo y el budismo, es comprendida en el sur de Asia como potencial de liberación espiritual ante la codicia capitalista de occidente. Se alirma que la crítica política y socioeconómica no es suficiente para lograr la liberación humana. Lo que se requiere para superar la codicia materialisı del capilalismo es la práctica de la pobreza espiritual, tan acorde con la pobreza y la libertad evangélicas del cristianismo. Ciertamente, la pobreza religiosa de Asia puede ser interpretada en este sentido. Sin embargo, la práctica de la pobreza religiosa, por profunda que sea, no es suficiente por sí sola para superar los problemas socioeconómicos. El problema metodológico, por tanto, consiste en cómo relacionar dicha práctica con la crítica socioeconómica y la praxis revolucionaria en la historia.

74. El problema de la fundamentación bíblico-cristológica consiste en poner en relación los contexlos históricos las luchas y los movimientos de liberación de los pueblos oprimidos del tercer mundo y su herencia religioso-cultural con 
los textos bíblicos, sus fuentes y nornatividad.

75. El principio formal del método herncnéutico biblico, circularidad entre el texto y el contexto, ha sido explicado prototípicamente por Bultmann y su escuela, y este principio metodológico es adoptado y muy sujeto a discusión por los teólogos latinoamericanos, aunque el contexமo, en este último caso, es muy nuevo para los europeos; es decir, el contexto de los pueblos oprimidos del tercer mundo es diferente del contexto occidental.

76. De acuerdo al principio circular de la hermenéutica, el texto y el contexto son norma y fuente codeterminante en la elaboración de la teología. Y aquí radica un serio problema. Pues si son codeterminantes, entonces el testimonio bíblico de la soberanía de Dios en la historia, el hecho escatológico, redentor y revelador de Dios en Jesucristo o el acontecimiento mismo de Jesucristo, quedan relativizados. En este caso, bien puede decirse, como lo afima Herbert Brown, teólogo existencialista de la escuela de Bultmann, que Jesús es la variable, y la existencia humana es la constante.

77. Por decirlo de otra forma, a Jesús se le puede tomar fácilmente como símbolo de la existencia (como en el caso de Friz Buri), o como ejemplificación del principio de la revolución histórica, tal como se sugiere en el énfasis dado al Jesús histórico por la teologia de la liberación latinoamericana, o como símbolo espiritual religioso, como en el caso de la teología de religión-cultura en Asia o en Corea. Tal ejemplilicación revolucionaria puede que sea superada por otras figuras revolucionarias. Tal símbolo religioso-cultural puede perderse entre la multitud de otros símbolos, imágenes, mitos y espíritus.

78. Para evitar este peligro hay que mantener la prioridad y la especificidad de Jesucristo que se fundamenta en el hecho redentor escablógico de Dios, tal como lo explicita típicamente Karl Barth. La prioridad de la norma y de la fuente bíblica en la elaboración de la teología esí lundamentada en su dar testimonio de Dios. Presupuesta la prioridad de Dios, puede mantenerse la relación codeterminante o circular de texto-contexto. Esta prioridad es el núcleo mismo de la tradición cristológica trinitaria, que necesita ser reinterpretada ahora en los contextos del tercer mundo. Este núcleo cristológico, aunque formulado tradicionalmente en conceptualización melafísica, apunta a Dios en cuanto tal, como el sujeto actuante en Jesucristo en la historia. En las teologías del tercer mundo y en la teología feminista de Estados Unidos existe la tendencia general a valorar al Jesús histórico más que la tradición cristológica, por ser ésta de corte metafísico o especulativo y por hacer abstracción de la historia; esta situación es semejante a la del liberalismo del siglo XIX y a la escuela del Jesús histórico en la cual la dimensión escatológica reveladora de Jesucristo se redujo al Jesús histórico como símbolo religioso-cultural o religioso-moral. Las teologías del tercer mundo hoy en día presentan un problema semejante al de la escuela del Jesús histórico.

79. El mismo tipo de problemas se observa en la tradición cristológica occidental, en la cual la prioridad divina y el señorio de Jesucristo quedaban, y 
quizás lo están todavía, identificados con la cultura cristiana occidental. De esta forma, las misiones cristianas a los pueblos del tercer mundo significaron, de hecho, su "occidentalización" o su sometimiento a la cultura cristiana occidental. Esa es, precisamente, la concepción-soteriológica no cristológica y no evangélica según la cual los blancos cristianos y sus conversos de entre los "paganos" son salvados en el cielo mientras que la mayoría de los paganos no creyentes están condenados al infiemo. La cristiandad y las misiones occidentales han tergiversado, por lo tanto, el evangelio cristiano, como si ellos fueran el criterio de salvación. La prioridad de Jesucristo y su sefiorio en la historia significan que toda la humanidad se encuentra en relación directa con él. No existen ya paganos excluidos.

80. En conclusión, dos puntos deben mencionarse. Primero, la prioridad y el señorío de Jesucristo significan para el occidente dominante el juicio divino, el cual ahora toma cuerpo en los movimientos de liberación de los pueblos del tercer mundo. Segundo, al reconocer su prioridad y su sefforío y la prioridad de las luentes bíblicas para el quehacer teológico, las diversas espiritualidades religiosoculturales de otras les pucden ser reinlerpretadas y apropiadas en los procesos históricos como dimensiones y fuentes creaturales en el quehacer teológico.

\section{B. Cuatro metodologias emergentes en Asia}

81. La teología minjung toma su nombre del têrmino coreano minjung, el cual significa, en general, el pueblo común o las masas del pueblo coreano las cuales han sido privadas de sus derechos humanos básicos, tanto políticos como socioeconómicos. Surgió en Corea, en la década de los setenta, del compromiso teológico con el movimiento popular a favor de los derechos humanos, la democratización y la justicia social y económica. La teología minjung ha propuesto el método de describir y descubrir relatos o biografias minjung como crítica a la forma lógica de hacer teologia en occidente. Entre la juventud el concepto de minjung ha incorporado ahora dentro de sí mismo el concepto de la revolución social marxista. La juventud se opone a las potencias opresoras, nacionales e internacionales, tales como el sistema de alianza militar CoreaEstados Unidos-Japón y la dominación de la economía coreana por Estados Unidos y Japón. La teología minjung se encuentra ante el desafío de dar cuenta de este movimiento. La pregunta, entonces, es cómo y hasta qué punto puede ser adoptado teológicamente el marxismo.

82. Hay que mencionar también la "teología del pueblo" en Corea, especificamente preocupada por la reunificación del país. En primer lugar, esta teología incluye también el concepto del minjung, pero incorpora a lodo el pueblo coreano como el sujeto de la reunificación. El pueblo, como tema teológico, plantea la necesidad de la liberación nacional de las potencias dominantes internacionales, tales como Estados Unidos y Japón. En segundo lugar, el concepto de pueblo coreano, ligado al concepto del minjung. planitea la necesidad del cambio social. Sin embargo, la tarea de unificación y de cambio social hacia una 
sociedad igualitaria no puede hacer su opción simplemente en términos marxistas. El concepto de la "tcrcera vía," descrila anteriormente en términos teológicos, se relaciona específicamente con la tarea de la unificación y, al mismo liempo, con la tarea del cambio social.

Más aún, el concepto de minjung implica las divisiones de clase entre el pueblo coreano. Sin embargo, la unilícación de Corea no puede lograrse exclusivamente por una parte del pueblo o por el minjung solamente, aunque el pueblo como sujeto de la historia debe tomar en cuenta seriamente la cuestión del minjung en la búsqueda de una Corea uníficada y una nueva sociedad para el futuro. El problema de la unificación de Corea no puede entenderse como un problema sólo de Corea. La división de Corea refleja el problema y los males de las potencias e ideologías de un mundo dividido, bajo las cuales el tercer mundo sufre y lucha por lograr la liberación y la transformación del mundo entero. Este problema universal común ha adquirido una forma peculiar en la división de Corea. Metodológicamente, persiste la cuestión de cómo reinterpretar el concepto del pueblo coreano y de otros pueblos dentro de sus respectivas herencias e historias religioso-culturales.

83. La metodología de una teología de lucha, la cual está surgiendo en las Filipinas, tiene las siguientes características:

a. el compromiso que supone paricipar permanentemente en la lucha popular es el punto de partida de la reflexión tcológica hoy en día;

b. el análisis económico-político y socio-cultural-religioso del contexto histórico concreto es un segundo elemento vital;

c. nuestra herencia de fe (la Biblia, las tradiciones de la Iglesia, otros elementos de la fe viva del pueblo) nos empujan a descubrir, develar y revelar la acción liberadora del creador y Seffor de la historia. Esta revelación juzga, ilumina, reta e inspira nuestra acción;

d. la experiencia de la presencia y la acción de Dios en el contexto histórico queda articulada en un nuevo lenguaje, símbolos, mitos, imágenes, y en una nueva liturgia que es relevante y comprensible por los pueblos en lucha;

e. las conclusiones teológicas tentativas son tomadas en común, sujetas a la crítica de los participantes más importantes en el proceso de liberación, es decir. los pobres y los oprimidos, y aquellos que echan su suerte con ellos.

84. La amplia pluralidad de las sociedades asiáticas nos empuja hacia una metodología que intenta, por un lado, purificar las religiones y las ideologías de sus aberraciones e insuficiencias, $y$, por el otro, que penetra en los profundos valores centrales, positivos y plenificadores para todos. Este mélodo, en el caso de América Latina, significa una apertura al humanismo, al secularismo y al marxismo, como lambién en el caso de Europa y Norte América. En el caso de Asia y Africa, supone un replanteamiento más profundo del contenido espiritual de las religiones y las culturas, las cuales requieren también de una purificación. 
Una leología adecuada al contexto asiático liene que purificarse del fundamentalismo religioso que se muestra sospechoso de y es antagónico a otras religiones. Debe generar una genuina renovación religiosa que busca servir a todos los seres humanos sin distinción de raza, sexo, credo, casta y culura.

84.1. La formulación de una tal teología exige la sensibilidad de escuchar a lo que dicen otros, el diálogo franco, el servicio desinteresado y dar humilde lestimonio de las propias convicciones sin motivos ulteriores de promover la religión propia a expensas de la de otros. De ahí que el diálogo entre las religiones es también un aspecto del método para hacer teología El diálogo con el secularismo, el humanismo, el ateísmo y el marxismo está también relacionado con dicho método, tanto porque tales escuelas de pensamiento están presentes en estos países, como porque las religiones antiguas tienen variadas tradiciones filosóficas y espirituales que muestran afinidad con los valores positivos de aquéllos.

84.2. Dentro de esta perspectiva se recomienda el siguiente enfoque:

a. la aceptación de fuentes pluriformes de revelación;

b. la purificación de la teología mediante el discemimiento de todo lo que degrada e insulta a sectores de la humanidad y la eliminación de sus causas en deterninadas construcciones teológicas;

c. la búsqueda mediante el diálogo franco, de los valores centrales de Jesús y de otras religiones e ideologfas, y el trabajo activo conjunto para su realización en sociedades determinadas;

d. la simplificación de la teología para que sea más fiel en las situaciones reales de nuestras vidas a Jesuís y al reino de Dios que anunció.

84.3. Todo esto supone una hermenéutica que pueda llegar a tener un impacto profundo en la teología, si se aplica con discemimiento riguroso, con convicción y con compromiso profundamente contemplativo. Jesús y su mensaje necesitan ser liberados del cautiverio de construcciones teológicas dominantes y de aquellos que pretenden tener control sobre él y su mensaje. La metodologla descrita anteriormente apunta a un proceso para lograr tal liberación, tal como es exigida en nuestras sociedades plurales. 